Pobrane z czasopisma Wschód Europy http://journals.umcs.pl/we

Data: 26/04/2023 03:38:46

\begin{tabular}{|l|l|}
\hline D0I:10.17951/we.2020.6.1.227-232 & Wschód Europy • Восток Европы • East of Europe vol 6, 1 / 2020 \\
\hline
\end{tabular}

Вальдемар Жак

ORCID ID: https://orcid.org/0000-0002-3388-4821

Университет Марии Склодовской-Кюри в Люблине, Польша

\title{
Recenzja książki: Leszek Sykulski, Rosyjska geopolityka a wojna informacyjna, PWN, Warszawa 2019, ss. 160
}

4

итатели, заинтересованные расширением знаний в области геополитики и политической коммуникации, с большим интересом приняли публикацию кандидата политических наук, доцента кафедры наук о безопасности Гуманитарно-Естественного Университета им. Яна Длугоша в Ченстохове Лешека Сыкульского. Результаты своего исследования он представил в своей монографии «Российская геополитика и информационная война» (Rosyjska geopolityka a wojna informacyjna).

Обосновывая причину выбора вышеуказанной тематики, автор обращает внимание, что геополитика заменила в России коммунизм и выполняет функцию идеологии. Кроме того, он указывает на то, что географическое пространство России было и есть одним из важных факторов, на которые опираются исследования, касающиеся ее истории, внешней и внутренней политики и безопасности государства.

Главная цель монографии - представить, как и на каком уровне современная геополитическая мысль воздействует на проведение Россией информационной войны как инструмента внешней политики и безопасности. Структура книги отвечает всем требованиям, предъявляемым к научной публикации. Автор систематизировал содержание работы в пяти разделах, что способствует четкому восприятию текста публикации.

В первой главе - Геополитика как исследовательская школа в общественных науках - автором было представлена дефиниция геополитики, в т. ч. в понимании немецкого геополитика Адольфа Грабовского, для которого геополитика исследует в первую очередь «пространственную динамику», для нее не существует понимания настоящего, существует только прошлое и будущее. Самое главное для неё уловить ключевые процессы, управляющие в сфере международной политики (с. 15). Автор также уделяет внимание бинарной парадигме в современной геополитике (противостояние союза Суши: Россия, Китай, Ближний Восток 
и Европа и союза Моря: США, Великобритания, Австралия и Япония). В заключении главы автор представляет геополитические модели Хэлфорда Джона Маккиндера, Николаса Джона Спикмэна, Карла Хаусхофера, а также мировозрения самого известного российского теоретика геополитики Александра Дугина, который является сторонником современной бинарной парадигмы и построения евразийской цивилизации.

Во второй главе, Российское «пространственное мыциление»-генезис и современность, автор акцентирует внимание читателей на том, что без глубокого анализа генезиса российской геополитической мысли трудно понять традиции и современность российского империализма и самодержавных устремлений. В понимании этого автор отсылает читателей к наследию Византии и сущности «пространственного мышления», которые выступают важными факторами в осознании миссии России так и в ее современной империальной концепции. Среди основоположников российской геополитики автор перечисляет: Георгия Вернадского, Николая Бердяева, Николая Данилевского, Константина Леонтьева, Владимира Ламанского, Льва Мечникова, Вениамина Семенова-Тянь-Шаньского и Алексея Вандама. Среди главных идеологических течений, на которых доминирует геополитическая школа современной России, автор выделяет - евразийство, византизм и западничество, что четко прослеживается в концепциях «Москва - Третий Рим» и «Русский Мир», где предопределено единство православного и русскоязычного населения без учета государственных границ. Данные концепции опираются на неповторимую русскую цивилизацию, совместное культурное, языковое и религиозное наследие. По мнению Сыкульского, концепция «Русский Мир» де-факто является геополитической доктриной, дающей идеологическую легитимизацию действиям Москвы на постсоветском пространстве (с. 27). Кроме того, прослеживается формирование концепции неовизантизма, вписывающейся в так называемую культурную геополитику, предполагающую активное использование общественных объединений, учреждений и культурно-просветительских центров по навязыванию определенных политических взглядов. Автор указывает, что на формирование современной геополитической мысли в России существенное влияние имела деятельность Русского географического общества, основанного в 1845 г. Так, член Русского географического общества, географ, картограф Александр Радо, который дал дефиницию геополитики в Большой советской энциклопедии (1929 г.), следующим образом трактовал в научных категориях геополитику, считая, что вдумчивый географический и исторический анализ при использовании научных методов может привести к открытию полных закономерностей в исследований политических процессов и формированию научных законов (с. 34). Взгляды Александра Радо на внешную и военную политику СССР остаются по настоящее время важным элементом формирования стратегической культуры среди российских элит.

В третьей главе - Современное измерение российской геополитической мысли - представлена доктринальная триада: евразийство-западничесто-изоля- 
ционизм, где последовательно изложены вышеперечисленные направления во внешней политике, которые подкреплены империальной идеологией. Символичной датой рождения евразийства является 1921 г., когда в Софии вышла популярная в политических элитах России работа «В борьбе за евразийство». Автор проследил этапы развития неоевразийства в современной России, отметив, что третий этап с 2001 г. по настоящее время является попыткой расширения через неоевразийское движение своего геополитического положения за пределами российских границ. Среди самых известных представителей неоевразийства автор упоминает: Александра Дугина, Александра Солженицина, Гейдара Джемаля, Геннадия Зюганова, Владимира Жириновского и Наталию Нарочницкую. В главе широко представлены геополитические взгляды главного редактора газеты «Завтра» Александра Проханова, выступающего сторонником «пятой империи» в лице Евразийского союза и политолога Сергея Караганова, сторонника создания конфедерации Европейского союза и России под эгидой Союза Европы (интеграция европейского континента от Лиссабона до Владивостока).

Особого внимания, по мнению автора, заслуживает анализ геополитических взглядов философа и идеолога Александра Дугина, основанных на синтезе политических доктрин, философской мысли, элементов теологии и социологии международных отношении. Заслугой автора является представление читателю подробной биографии Дугина, формирования его политических взглядов, а также этапов его общественно-политической деятельности на рубеже XX-XXI веков. Отдельно представлена публикационная активность Дугина, опубликовавшего около 60 книг не только по классической геополитической мысли, но и учебники («Основы геополитики», «Геополитика»), книги о социологии международных отношений, а также по проблематике спецслужб («Конспирология») и философии Мартина Хайдеггера (с. 58-59). Автор признает, что геополитические аргументы Дугина имеют сильное обоснование в т.ч из области сакральной географии т.е. сферы знаний, которая приписывает разным пространствам сакральный характер. Главная идейная матрица Дугина закладывает противостояние двух цивилизаций, символизирующих противоположенные ценности. Согласно «четвертой политической теории» Дугина, западное общество стало «обществом зрелища», лишенного глубокой духовной жизни, основанного на потребительской философии, дешёвом развлечении, а также противоречиях в политической сфере (демократия основана на медиаиндустрии), тем самым определив идеологическое состояние Запада как «метафизики мусора», что послужит дальнейшему распаду западной цивилизации и позволит влиять на неё со стороны российского центра силы (с. 63-64).

В начале четверной главы Сущность российской силь автор представляет «стратегические коды», имеющие влияние на формирование внешней и экономической политики современной России, среди которых обоснованно выделил: 1) физический компонент (географическая протяженность, климат, демографическая структура и природные ресурсы); 2) политический компонент (историче- 
ский опыт, стратегическое мышление политических элит, система организации силовых структур и дипломатии, а также политические технологии); 3) цивилизационный компонент (монголо-византийское наследие, мифотворчество и народная символика, отношение религии и государства, доминирующая идеология). По мнению автора монографии, анализ российских основ экономической политики и стратегической доктрины требует лучшего изучения первоисточников российской стратегической культуры.

Одной из главных основ российской дипломатии и военного искусства в реализации стратегической цели было и есть уклонение от таранной тактики т.е. действий прямолинейных и открытых. Применяется практика тонкой работы, т.е. действий, требующих мастерского исполнения данных правил, допускается закулисная борьба с широким использовании разного рода форм дезинформации, блефа, манипуляции, обмана и отвлечения внимания. Признается, что спектр влияния на массы очень широк и разнообразен. Американский политолог С. Коллинз утверждает, что Москва широко использует американские стратегии сетевых войн и инструменты в области психологической войны: информационные стратегии (public diplomacy), психологические операции (Psychological Operation - PsyOps) и скрытые операции. Главной формой реализации политических целей для России стала информационная война. По мнению автора, ключевыми трендами современной борьбы за пространство, имеющими черты гибридных войн является: 1) отсутствие формального объявления войны; 2) уклонение от официального участия государства в войне; 3) отсутствие линии фронта; 4) возрастающая роль спецподразделений войск и спецслужб; 5) решающее значение отведено длительному информационно-психологическому воздействию; 6) формальное отстранение вооруженных групп, участвующих в боевых действиях, от государства; 7) существенная роль психологического воздействия на общество (информационные войны) и др. (с. 72). Согласно автору, информационная война действует в трех плоскостях (географическом пространстве, ноосфере и киберпространстве). В концепции нелинейной войны ноосфера и киберпространство, по сути, приравнены к географическому пространству. Следовательно, нет линии фронта, борьба приобретает разные формы от психологических действий, кибератак до непостоянных действий. Одним из главных целей данного вида борьбы является введения атмосферы страха. Психология становится доминирующим инструментом проведения борьбы. Признается, что информационно-психологическое воздействие распространяется как в географическом пространстве, так и в Интернете.

В последней пятой главе Геополитика как инструмент инбормационной войнь представлена дефиниция информационной войны, а также ее отличие от информационной борьбы. Важным элементом проведения информационной борьбы становится фрагментаризация общества, а затем общественного мнения, что позволит проще управлять большинством через дисциплинированное меньшинство. Существенную роль проводимого нарратива играет его эмоциональное измерение, которое, по замыслу инициаторов, часто приводит 
к иррациональному восприятию объектов информационного влияния. Нарратив основан на скрытых схемах, клише, мифах, предубеждениях, стериотипах, симпатиях и антипатиях общества, использования всякого рода ассоциации и правил всеобщего одобрения, а также очевидности данных взглядов. Часто это приводит к фальсификации информации, основанных на частично достоверной или недостоверной информации (fake news). Главная эмоция, на которой основан нарратив информационной борьбы, это чувство страха. В перспективе информационная борьба может стать самостоятельным элементом политики государства, направленная на достижение политических и экономических целей без использования непосредственно физической силы.

Автор осознает, что крайне важной областью массового информационного воздействия стал Интернет. В геополитических исследованиях эту область отмечают как «экстра территория» - дополнительное пространство борьбы, которое зачастую превосходит физическое пространство. Связано это с появлением новых явлений, таких как троллинг - форма информационного воздействия, основанная на массовом распространении мемов в Интернете. Через мемы проходят информационные потоки (слова, предложения, символы, анимации и фрагменты фильмов), имеющие целью воздействать на эмоции получателя информации, представляя конкретное событие. Троллинг становится инструментом идеологической диверсии, направленной на дезинтеграцию, автономность, раздел конкретной группы или целого общества. Автор обращает внимание, что российская стратегическая мысль в т.ч. геополитическая мысль, заимствовала многие понятия на Западе (теория сетевой войны (netwar), сетецентричная война, экспорт ценностей, петля Бойда, цикл НОРД Наблюдение-Ориентация-Решение-Действие). В монографии подробно описана роль информационной борьбы в российской теории нелинейной войны, в т.ч. в концепции военного теоретика Евгения Месснера, по проведению боевых действий, получившая название «мятежная война». Главный тренд мятежной войны это отсутствие линии фронта и государств. Другая концепция диффузной войны, без использования вооруженных сил, принадлежит российскому государственному деятелю Владиславу Суркову. Ведущий тренд в диффузном конфликте - неизвестность и неожиданность. Автор подчеркивает, что стратегические интересы России в контексте геополитики можно определить как многовекторные. В первую очередь они направлены на обеспечение политического влияния на постсоветское пространство (т.н. ближнюю заграницу). Основным постулатом является создание Евразийского союза. Следующий шаг - расширение влияния на государства бывшего Варшавского договора. Далее продвижение российских интересов в Арктике. Стратегическая цель это российско-немецкое партнерство, которое базируется на классической геополитической теории Карла Хаусхофера, а также создании оси стратегического партнерства Москва-Берлин-Париж.

Стоит признать, что монография ориентирована на геополитические аспекты, чем на аспекты политической коммуникации. Также необходимо отметить, 
Pobrane z czasopisma Wschód Europy http://journals.umcs.pl/we

Data: 26/04/2023 03:38:46

что автор при написании монографии опирался в основном на публикации, изданные за пределами России, что прослеживается при анализе библиографического списка. Обобщая полученные результаты исследования, автор сумел обозначить огромный потенциал данной тематики, выразив надежду на использование монографии для дальнейшего углубленного исследования тематики российской геополитики и информационной войны.

Данная монография адресована специалистам в области политологии, международных отношений, национальной безопасности, журналистики, а также всем тем, чьи интересы ориентированы на изучение российской геополитики и информационной войны. Рекомендую читателям ознакомиться с указанной монографией для расширения своих компетенций в области внешней политики и отношений с Россией. 